\title{
Neuroendocrine tumor of stomach
}

\author{
INSERM
}

\section{Source}

INSERM. (1999). Orphanet: an online rare disease and orphan drug data base.

Neuroendocrine tumor of stomach. ORPHA:100075

Gastric neuroendocrine tumor is a rare subtype of neuroendocrine neoplasm, arising from enterochromaffin-like cells in the stomach, with a variable clinical presentation, disease course and prognosis, depending on the disease type and histological grade. Most patients are asymptomatic, with diag nosis usually occurring incidentally during gastroscopy, however, symptoms of dyspepsia, anemia, pain, weight loss and gastrointestinal bleeding can be observed. Association with Zollinger-Ellison syndrome and multiple endocrine neoplasia type I has been reported. 